\title{
Postglacial sea-level rise and sedimentary response in the Guadiana Estuary, Portugal/Spain border
}

\author{
T. Boski a, ${ }^{*}$ D. Moura a, C. Veiga-Pires a, S. Camacho a, D. Duarte a, \\ D.B. Scott b, S.G. Fernandes a \\ ${ }^{a}$ CIMA-Centro de Investigacao Marinha e Ambiental, FCMA, Universidade do Algarve, Campus de Gambelas, 8000 Faro, Portugalß \\ bCentre of Marine Geology, Dalhousie University, Halifax, Nova Scotia, Canada
}

\begin{abstract}
The study of sedimentological features, foraminifera and molluscan fauna in samples recovered from four rotary boreholes permitted, after ${ }_{14} \mathrm{C}$ dating, the first assessment of the post-glacial transgression in Guadiana River Estuary. The Holocene sequence is underlain by coarse sediments from delta fan enclosing continental swamp deposits dated 16980 year BP. The Holocene sedimentary sequence was deposited either directly on this delta fan gravels or on top of fluvial sands deposited probably between 11000 and $10000 \mathrm{yr}$ BP. An accelerated phase of the estuary infilling by clayey sediments containing the salt marsh foraminifer Trochammina, began ca. 9800 year BP, when sea level was about $39 \mathrm{~m}$ below present. Between 7500 and 7000 year BP, the central part of the estuary started to accommodate coarser sediments, partially introduced from the continental shelf. The first phase of Holocene sea-level rise at a rate of $0.85 \mathrm{~m} /$ century terminated ca. 6500 year BP. Since then, lagoonal sediments in the vicinity of the estuary have been enclosed behind sand spits and predominantly sandy sedimentation was initiated within the estuary. After a second phase of slower rise at the rate of $0.3 \mathrm{~m} /$ century, which lasted until ca. 5000 year BP, the sea approached the present level.
\end{abstract}

\section{Introduction}

Due to rapid sedimentation during the most recent postglacial transgression, estuarine sedimentary records offer excellent opportunities to study the sequence of events which have led to the present morphology of the coast. There are several published studies dealing with the Spanish portion of the Gulf of
Cadiz estuarine valley infilling during the Holocene. The Guadalete Holocene sequences were studied by Dabrio et al. (1995) and Goy et al. (1996). Borrego et al. (1993) discussed results of a study on an infilling sequence in the Piedras Estuary. Dabrio et al. (2000) presented the most recent synthesis of a regional overview, based on new material from boreholes and trenches in Tinto -Odiel Estuary, Guadalete Estuary and San Pedro Estuary. To date, the most comprehensive work on the recent distribution of sedimentary facies in the terminal stretch of Guadiana was published by Morales (1997). However, no data have yet 
been published about the deep structure of Guadiana valley infill. This paper fills that gap with a discussion based on the interpretation of sedimentological records, macro and micro paleontological data, and ${ }_{14} \mathrm{C}$ dates. This dataset was gathered from four continuously cored boreholes that were drilled in the area of Guadiana River estuary in 1997 and that samples the complete sequence of sediments accumulated since the Last Glacial Maximum. This study embraces the Holocene history of the terminal segment of this major river course.

\section{Geographic and geological setting}

The Algarve is the southernmost region of Portugal. It covers $5019 \mathrm{~km} 2$ and embraces three geomorphological zones (Fig. 1). The Hercynian mountains in the north which belong to the Hesperic Massif are essentially composed of shales and graywackes. The central zone is occupied by Jurassic and Cretaceous formations, composed essentially of limestones, marls and dolomitic limestones, strongly karstified. The southward littoral fringe is dominated by clastic limestones and siliciclastic sediments, respectively dated from Miocene and Plio-Pleistocene. The Algarve Basin started to form in the Late Triassic during the early phase of North Atlantic opening, under E - W to ENE WSW distensional regime (Pereira, 1992). The present morphology of the continental shelf has been shaped since the Neogene (Mougenot, 1988). The shelf evolution since the Tortonian, involved switching from carbonate reef to terrigenous sedimentation, in semigraben structures, leading to the accumulation of tens of meters of sands, (Moura and Boski, 1999) exposed along the cliff shores between Albufeira and Faro. These cliffs exhibit marked contemporary erosion which in some places results in up to $10 \mathrm{~m} /$ year of shore retreat (Correia et al., 1996) and is a major source of sand to the Ria Formosa barrier system.

Guadiana is one of the most important rivers on Iberian Peninsula, whose total length is $730 \mathrm{~km}$ of which the last $200 \mathrm{~km}$ forms a natural border between Portugal and Spain (Fig. 2). In this section, the river bed is cut into the Hercynian basement consisting of Carboniferous schists and graywackes and follows $\mathrm{N}-\mathrm{S}$ path defined during Quaternary (Vidal et al., 1993). The resistance offered by the basement rocks to the river erosion, defines the pattern of the bedrock river valley which is narrow and deep: $600 \mathrm{~m}$ wide and about $70 \mathrm{~m}$ deep below mean sea level, ca. $7 \mathrm{~km}$ inland from the mouth. According to Borrego et al. (1993), these characteristics distinguish Guadiana Estuary from the other estuaries in the Guadalquivir Basin, which are cut into soft non-consolidated PlioPleistocene sediments, resulting in broader and shallower structures. Only the terminal $5 \mathrm{~km}$ of the river valley is underlain by Cretaceous and Jurassic limestones which enabled a broader opening of the estuary, accommodating the extensive salt marshes on both sides of the inlet.

From the hydrographic point of view, the estuary, like others in the Gulf of Cadiz, experience a mesotidal regime (Morales, 1997). The predominant southwest waves are responsible for the eastward longshore current and sediment transport towards the east (Bettencourt, 1994; Granja et al., 1984). The accretion of drifting sands in the proximity of the main channel mouth which are continuously reworked by wave action, has led to the formation of the highly mobile washover banks and to the fast migration of the estuarine channels. The volume of sand deposited behind the groin constructed in 1958 aiming to shelter the river mouth, is approximately $5.6 \hat{\mathrm{A}} 106 \mathrm{~m} 3$ (accreted area $=2.07 \mathrm{~km} 2$; average thickness $2.7 \mathrm{~m}$ ). This gives an accumulation rate of ca. $176 \hat{\mathrm{A}} 105 \mathrm{~m} 3$ year1, which is almost identical to the rate proposed by Cuena (in Morales, 1997). The retention of drifting sands by the groin on one hand and the retention of terrigenous material by more than 40 major dams constructed in the Guadiana drainage basin on the other hand, creates the present sediment-starved situation and has caused erosion of the longshore barriers and spits, sheltering lagoons and salt marshes to the east in Spain, which were formed since the mid-Holocene stabilisation of mean sea level.

\section{Material and methods}

The rotary drillings were carried out by means of WIRTH Bo drilling rig operated by Portuguese Geological Survey (IGM). The location of the drilling sites is marked on Fig. 2 and detailed in Table 1. The borehole walls were protected by steel casing and the cores were recovered into plastic $6 \mathrm{~V}$ coreline 

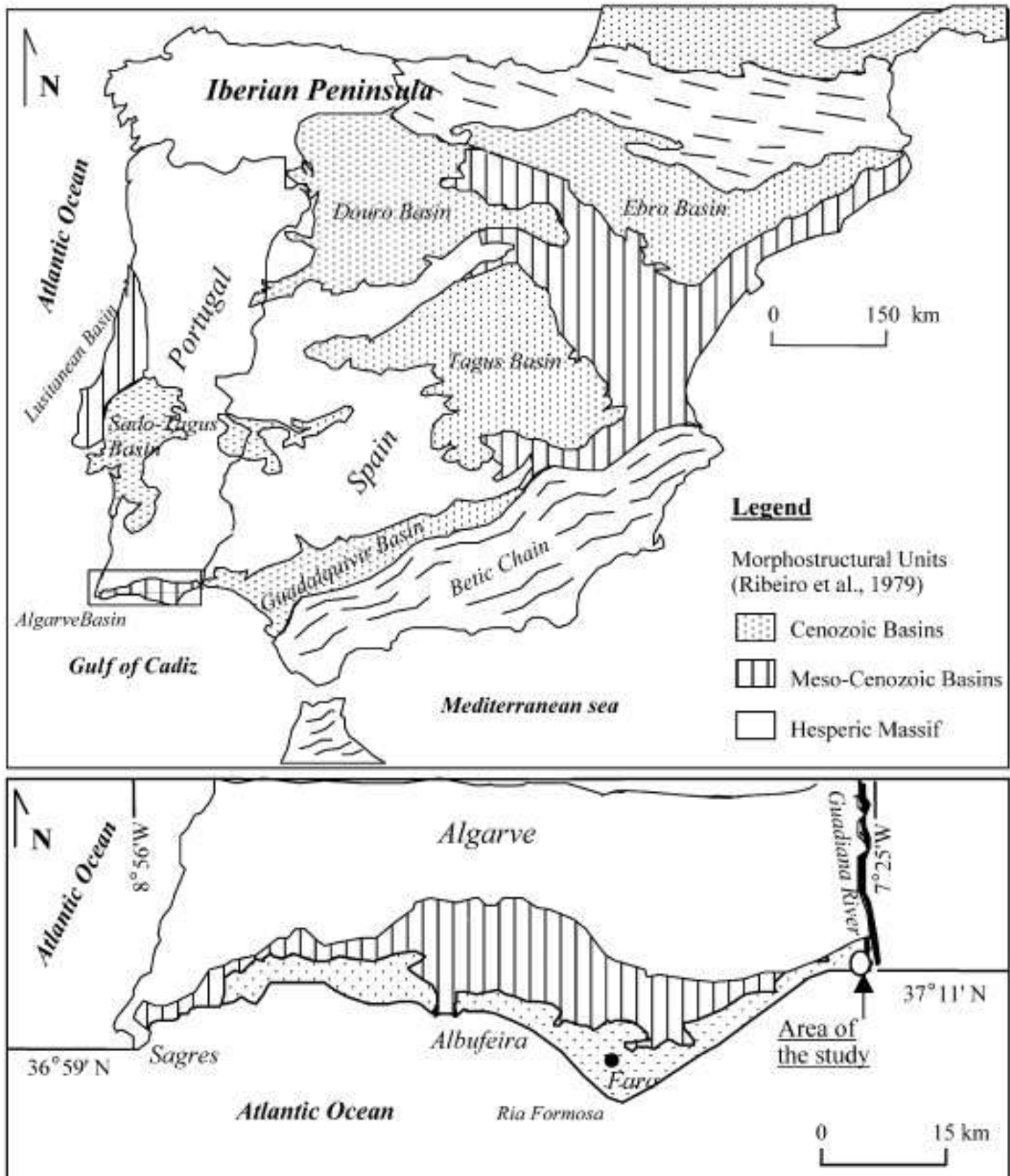

Legend: Principal structural units in Algarve

Cenozoic: calcarenites \& siliciclastic sediments-Littoral Fringe $\quad \square$

Mesozoic: Cretaceous; sub-vulcanic Monchique massif

Jurassic \& Cretaceous: mostly limestones-Central Zone $\square$

Paleozoic: shales and graywackes-Hesperic Massif

Fig. 1. Location map of the study area in the Southern Iberian Peninsula. The principal morphostructural units are adapted from Ribeiro (1979). 


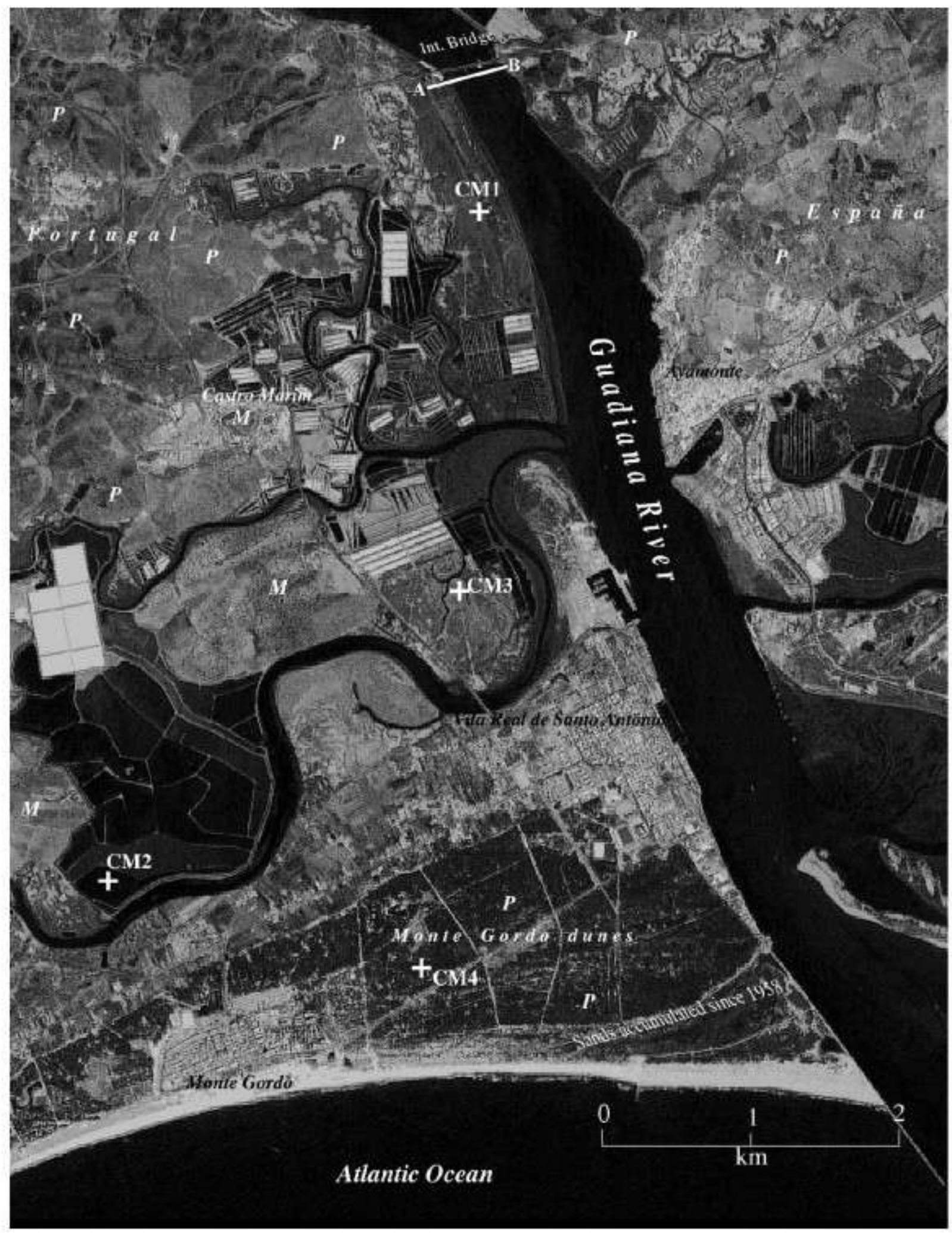

Fig. 2. IRS satellite panchromatic image of the Guadiana Estuary. Letters indicate basement rocks of the estuarine valley; P-Palaeozoic substratum , M-Mesozoic substratum. A - B is the line of profile shown in Fig. 9. CM1, CM2, CM3 and CM4 are the sites of boreholes. 
Table 1

Geographical and UTM coordinates of cored boreholes drilled in the area of Guadiana River Estuary

Borehole Geographical coordinates

UTM coordinates (295)

$\begin{array}{lllcc} & \text { Latitude } & \text { Longitude } & x & y \\ \text { CM1 } & \text { 37j13V13WN } & \text { 007j25V05WW } & \text { 0640242 } & 4121463 \\ \text { CM2 } & \text { 37j11V08WN } & \text { 007j27V12WW } & \text { 0636728 } & 4117881 \\ \text { CM3 } & \text { 37j12V06WN } & \text { 007j25V10WW } & \text { 0639536 } & 4119918 \\ \text { CM4 } & \text { 37j11V04WN } & \text { 007j26V02WW } & \text { 0638348 } & 4116019\end{array}$

$\mathrm{k}$ (Rocbore) tube. Recovery ranged from $60 \%$ (sands) to $100 \%$ (clays) with the average being $85 \%$.

The cores were further sectioned in two halves. One halve was archived and another sampled. The standard description of a core includes granulometry, macroscopic sedimentary structures and colour (according to Munsell chart). Shells of macrofauna were handpicked. Despite the fact that most of the mollusc remains in the sedimentary column exhibited a variable state of degradation due to taphonomic processes, in several sandy layers, extraction of well-preserved identifiable specimens was possible. These were used for dating purposes. The sediment, peat and wood samples taken for dating were all kept at À $20 \mathrm{jC}$ and freeze dried before being sent to the commercial laboratories which are referred in Table 2. Organic matter samples were taken always from the central part of the cores in order to avoid contamination.

Samples for microplankton analyses were sieved through 63- and 500-Am sieves after decanting organic debris. After sieving, samples with a high content of sand were dried and the sediment was sprinkled into carbon tetrachloride to float off the foraminifera. Samples with high content of organic matter or with extremely high total numbers of foraminifera were divided with a modified plankton splitter (Scott and

Table 2

Information about ${ }^{14} \mathrm{C}$ datings

Borehole sample Lab. code number

Depth $\quad{ }^{14} \mathrm{C}$ age (BP)

(cm)

$\mathrm{d}_{13} \mathrm{Cx}$

(PDB)

GX-25447

GX-25448

UtC-8376

SAC-1534

GX-25449

UTC-9691
$5020 \mathrm{~F} 310$

824
1712
1860
2127
2850
3606

$6210 \mathrm{~F} 220$

$6210 \mathrm{~F} 40$

$7590 \mathrm{~F} 100$

9500 F 70
8430 F 380

$\begin{array}{lr}1.1 & 5837 \\ (\text { À 25.9) } & 7155 \\ 2.08 & 7175 \\ 20 & 8848 \\ \text { na } & 9420 \\ \text { na } & 10765\end{array}$

$\begin{aligned} & \text { Cal BP } \\ & \text { age }\end{aligned}$


5837
7155
7175
8848
9420
10765

Materia

Method laboratory

C. glaucum
peat
C. edule
C. angulata
C. glaucum
C. glaucum

$\mathrm{h}$ radiometric $\mathrm{h}$ radiometric AMS

$\mathrm{h}$ radiometric $\mathrm{h}$ radiometric AMS

\section{$\mathrm{CM} 2$}

CM2.1

CM2.3

CM3

CM3.1

CM3.2

CM3.3

CM3.4

\section{CM4}

CM4. 1

CM4.2

CM4.3

CM4.4

$\begin{array}{llr}\text { Beta-128887 } & 200 & 3040 \text { F } 100 \\ \text { Beta-128886 } & 715 & 5950 \text { F } 190 \\ \text { SAC-1536 } & 854 & 10130 \text { F 200 }\end{array}$

459

960

1452

2690
3300 F 160

$6710 \mathrm{~F} 120$

7080 F 200

9470 F 250

$\begin{array}{lc}(\text { À 27.3) } & 2986 \\ 0.4 & 6794 \\ (\text { À 5.98) } & 11348\end{array}$

peat

A. tuberculata

shell remains $\mathrm{h}$ radiometric $\mathrm{h}$ radiometric $\mathrm{h}$ radiometric

$\mathrm{CM} 1, \mathrm{CM} 2$ and $\mathrm{CM} 3$ drill sites are at elevations between 0 and $1 \mathrm{~m}$ above MSL and were not taken into account. CM4 drill site elevation was at 4-m elevation and was reduced to MSL.

USA; SAC_-Instituto Tecnologico e Nuclear, Lisboa, Portugal; UTC_-

6200 F 340
5640 F 90
6250 F 250
16980 F 100

$\begin{array}{lc} & 3598 \\ 1.6 & 7594 \\ 0.7 & 7936 \\ (\grave{A} 22.9) & 10738\end{array}$
C. angulata
C. angulata
C. angulata

wood

$$
\begin{aligned}
& \text { h radiometric } \\
& \text { h radiometric } \\
& \text { h radiometric } \\
& \text { h radiometric }
\end{aligned}
$$

Institut Royal du Patrimoine Artistique, Brussels, Belgium. 
Hermelin, 1993). The splitter divides the sample into eight equal parts, and in some cases reported here, 1/8 of the sample was sufficient for a good statistical base (300 - 400 individuals). The processed samples were then examined under binocular microscope in a gridded circular counting tray.

Grain size analyses were carried out after carbonate elimination with $10 \% \mathrm{HCl}$. The samples were sieved through a 250-Am sieve and the fractions < $250 \mathrm{Am}$ were analysed in a Malvern Mastersizer Microplus instrument using filtered water with $1 \mathrm{~g}$ of Calgon per litre, added to avoid flocculation of clay minerals.

Several non-cored rotary drillings carried out before '1986 by the Junta Autonoma de

\section{Estradas (National}

Road Administration), prior to the construction of the International Guadiana Bridge, allowed the extrapolation of the depth of the limits between the described sedimentary bodies and of the bedrock channel within the profile $A-B$.

\section{Results-borehole descriptions}

\subsection{Borehole CM1}

The most landward CM1 borehole which is located in the tidally active salt marsh near Castro Marim reached bedrock at the depth of $42 \mathrm{~m}$. The following lithological units, were distinguished from bottom to top (Fig. 3).

\subsubsection{Unit I (À42.2 to À39.1 m)}

This pebbly layer is deposited directly on the paleozoic basement shales, where $80 \%$ of the particles are moderately rounded quartz and quartzite pebbles and $20 \%$ are platy graywackes and shales. Roundness and higher abundance of quartz in relation to the substratum, indicates recycling of this material from surface deposits, known regionally under the term of

"ranas". Ranas are coarse Pliocene-Pleistocene deposits that cover wide areas of the Pliocene plantation surface of the Iberian Peninsula. This origin is attributed to gravity flows during an arid climatic phase and/or to periods of tectonic uplift (Martin-Serrano and Molina, 1989; Cabral, 1995).

According to the results of non-cored geotechnical drilling (JAE, 1986 unpublished) ca. 700 m north CM1, this unit attains a thickness of $46 \mathrm{~m}$ in the deepest part of the valley, where the Carboniferous basement was reached at $70 \mathrm{~m}$ depth.

\subsubsection{Unit II (À39.1 to À20.6 m)}

The gravelly unit is overlain from $39.1 \mathrm{~m}$ depth upwards, by a monotonous sequence mostly composed of grey muds (5Y,3/1), sporadically interlayered with decimetre-thick layers of grey fine sand of similar hue, preserving flaser structures. Within the muddy layers, centimetre-scale bioclastic horizons, mud balls and vegetal remains frequently occur. Root remnants present in the highest part of this unit are preserved.

Cerastoderma glaucoma and Crassostrea angulata individual valves were recovered from sandy layers for dating (samples CM1.4, CM1.5 and CM1.6, Fig. 3 and Table 2). As said, most of the well-preserved shells were found within sandy layers. This would indicate that variation of faunal density and/or diversity was due to their differential preservation controlled by the chemical conditions within the sedimentary matrix (Walker and Goldstein, 1999; Aguirre and Farinati, 1999). This unit contains the highest number of bivalve species of this core and the identified (Table 3) specimens are characteristic of the intertidal zone. Gastropod shells are better preserved than the bivalves and are an important component of the bioclastic mass.

The foraminifera assemblage near the bottom, between 38.40 and $27.20 \mathrm{~m}$, is characterised by the highest individual numbers but the lowest numbers of species. The populations are almost entirely composed by Trochammina spp. inner linings or poorly preserved tests of this species. From $27.20 \mathrm{~m}$ to the top of the sedimentary unit which is marked by an erosion surface, both diversity and density are drastically reduced showing few or no foraminifera (Fig. 4).

\subsubsection{Unit III (À20.6 to À $18.7 \mathrm{~m}$ )}

This unit comprises a fining upwards sequence beginning with medium sand $(5 Y, 3 / 1)$ with lenticular clay intercalations of the same hue and channel bioclastic levels. The medium sandy facies is overlain by fine sand and yellowish clay, and is characteristic of a tidal flat environment (Trentesaux et al., 1999).

Mollusc remains show a high stage of dissolution and therefore were not dated. 


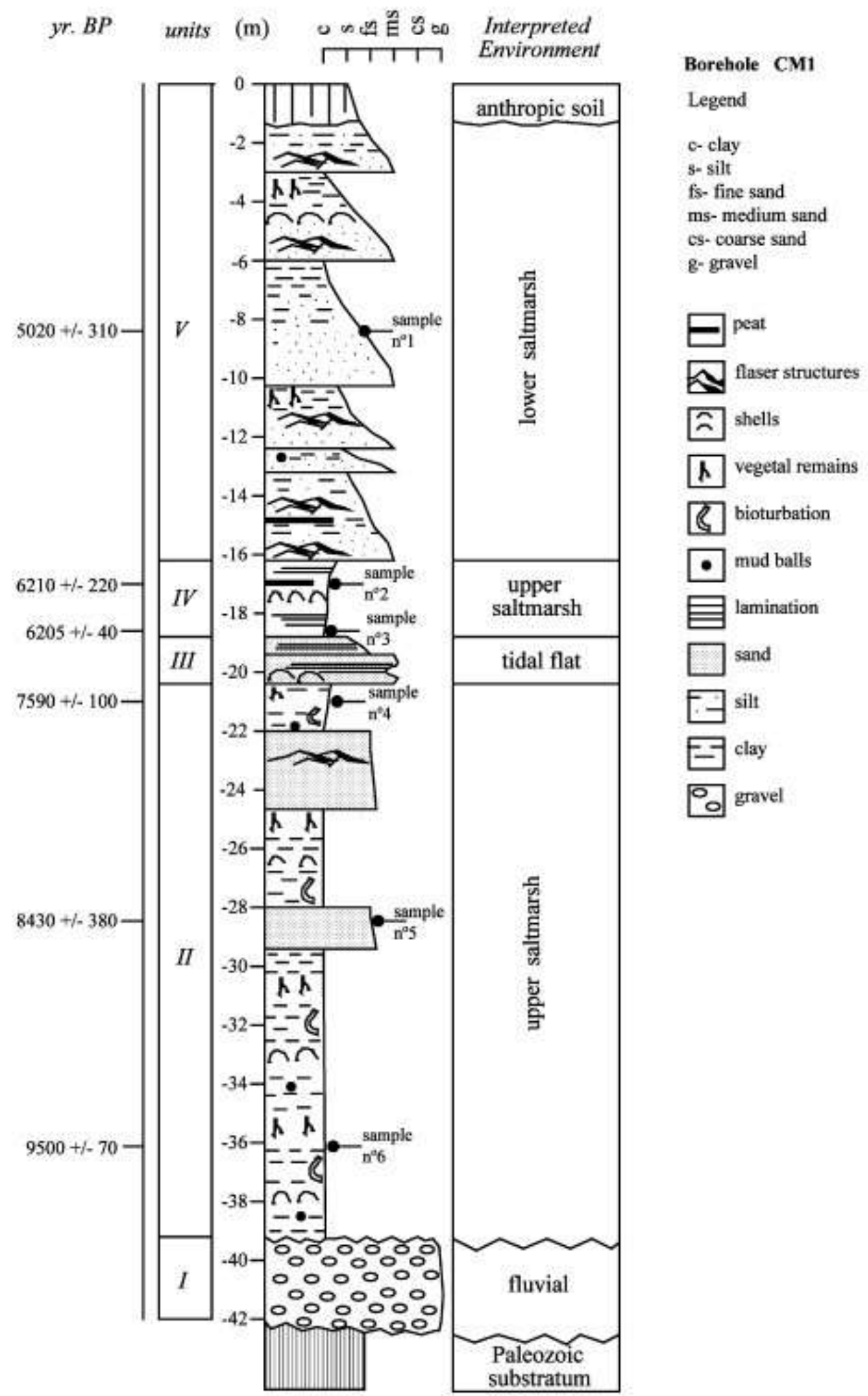

Fig. 3. Stratigraphic column from borehole CM1 and the inferred depositional environments. Depth referred to the borehole mouth elevated at $1 \mathrm{~m}$ above MSL. 
Table 3

Macrofauna identified in boreholes $\mathrm{CM} 1, \mathrm{CM} 3$ and $\mathrm{CM} 4$

\begin{tabular}{|c|c|c|c|}
\hline \multirow{3}{*}{ Species } & \multicolumn{2}{|c|}{ Sampling intervals in boreholes } & \multirow{3}{*}{$\begin{array}{l}\text { Sampling intervals (m) } \\
\text { CM1 } \\
\text { 1: } 9.08-12.12\end{array}$} \\
\hline & $\mathrm{CM} 1$ & $\mathrm{CM}_{3}$ & \\
\hline & I II III IV I & II III IV I II III IV & \\
\hline Bivalves & & & II: $17.87-18.60$ \\
\hline Acanthocardia pancicostata (1) & & & III: $20.85-23.42$ \\
\hline Acanthocardia tuberculata (2) & & & IV: $23.62-29.86$ \\
\hline Astarte sulcata (3) & & & $\mathrm{CM} 3$ \\
\hline Bornia geoffroyi (4) & & & 1: $5.24-7.25$ \\
\hline Bornia sebetia (5) & & & II: $7.40-9.80$ \\
\hline Cerastoderma edule (2) & & & III: $10.86-16.16$ \\
\hline Cerastaderma glaucum (6) & & & IV: $18.15-18.57$ \\
\hline Chlamys multistriata ( 7 ) & & & $\mathrm{CM} 4$ \\
\hline Clausinella brongniartii (4) & & & $\mathrm{I}: 2.99-8.70$ \\
\hline Clausinella fasciata ( 3 ) & & & II: $8.70-9.98$ \\
\hline Corbula gibba (8) & & & HII:9.98 - 10.90 \\
\hline Crassostrea angulata (9) & & & IV: $10.90-13.13$ \\
\hline \multicolumn{4}{|l|}{ Digitaria digitaria (2) } \\
\hline Donax semistriatus $(8)$ & & & Species reference \\
\hline Donax trunculus (2) & & & (1)-SOWERBY, 1841 \\
\hline Donax vemistus ( 8 ) & & & (2)- LINNAEUS, 1758 \\
\hline Dosina lupinus (2) & & & (3)- DA COSTA, 1778 \\
\hline Loripes lacteus (2) & & & (4)- PAYRADEAU, 1826 \\
\hline Lucinella divaricata (2) & & & (5)- COSTA O. G., 1829 \\
\hline Mysela bidentata (11) & & & (6)- POIRET, 1789 \\
\hline Nucula sulcata (12) & & & (7)- POLI, 1798 \\
\hline Ostrea edulis (2) & & & (8)- POLI, 1795 \\
\hline Paphia rhomboides (13) & & & (9)-LAMARCK, 1835 \\
\hline Pavicardium minimum (14) & & & (10)- LAMARCK, 1822 \\
\hline Psammobia fervensis (15) & & & (11)-MONTAGUE, 1803 \\
\hline Scrobicularia plana (3) & & & (12)- BROMM, 1831 \\
\hline Spisula solida (2) & & & (13)-PENMANNT, 1777 \\
\hline Spsisula subtruncata (3) & & & (14)- PHIL.IPPI, 1836 \\
\hline Vemus casina $(2)$ & & & (15)-GMELIN, 1791 \\
\hline Venus mox (15) & & & (16)-STROM, 1768 \\
\hline \multicolumn{4}{|l|}{ Gastropods } \\
\hline Calyptraea chinensis (2) & & & Environment \\
\hline Nassarius incrassatus (16) & & & intertidal \\
\hline Nassarius pygmaeus (10) & & & \\
\hline Nassarius reticulatus (2) & & & intertidal-infralittoral \\
\hline Ocenebra erinaceus (2) & & & \\
\hline Tomus subcarinatus (11) & & & Infralittoral \\
\hline
\end{tabular}


CM1 borehole

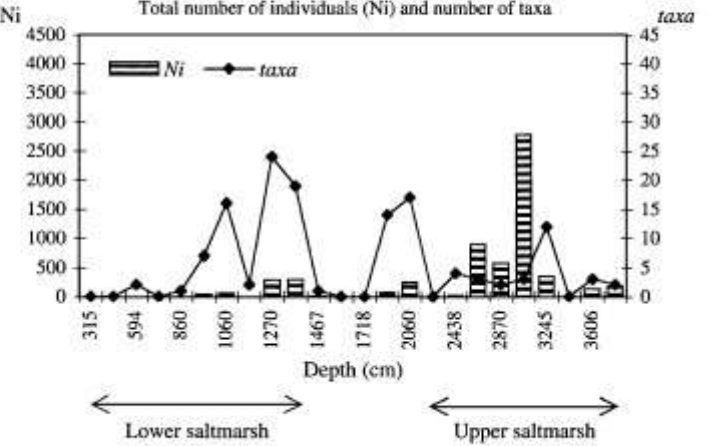

CM2 borehole

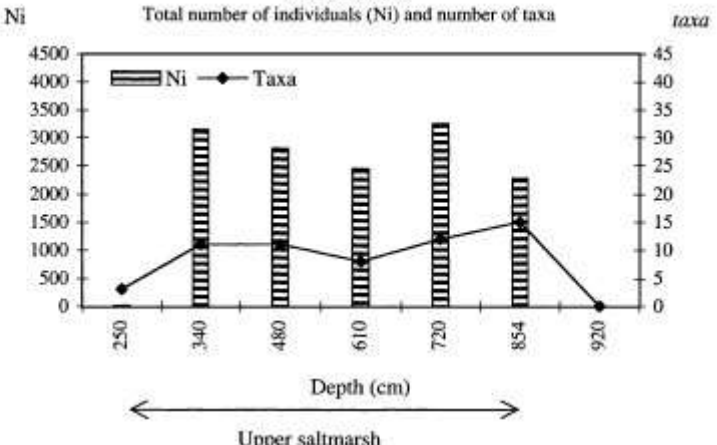

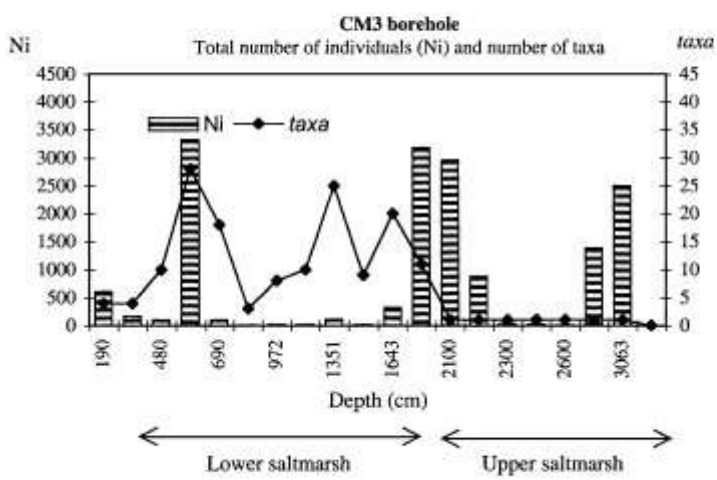

CM4 borehole

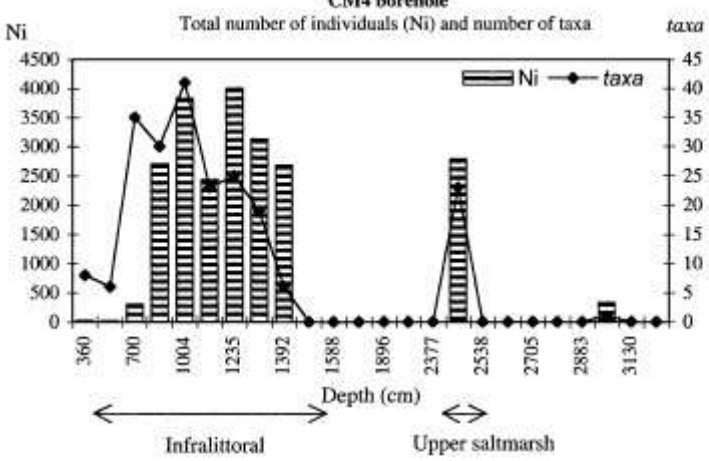

. Boski et al. Sedimentary Geology 150

Fig. 4. Foraminifera abundance plots in the sediments from boreholes $\mathrm{CM} 1, \mathrm{CM} 2, \mathrm{CM} 3, \mathrm{CM} 4$ and their ecological interpretation. The points refer to the centre of sampled interval. 
The foraminiferal assemblage consists of various calcareous species and is dominated by Haynesina depressula and Ammonia beccarii plus several species of Elphidium, ranging from 7 to 24 species per sample.

\subsubsection{Unit IV (À18.7 to À16.2 m)}

This unit is entirely composed of clay with sandy bioclastic levels from which $\mathrm{C}$. edule valves were taken for dating (sample CM1.3, Fig. 3 and Table 2). The list of all identified molluscs as well as the inferred environments are presented in the Table 3.

The lower part, consists of black clay $(2.5 \mathrm{Y}, 3 / 1)$ with peat interlayered by reddish, millimetre-thick clay laminae. The presence of rootlet traces below the peat laminae and lack of any evidence of erosion proves their undoubtedly autochthonous origin. They could form in a brackish environment of semiconfined ponds occasionally invaded by fresh water carrying reddish Fe oxide stained clay. Such ponds can be observed at present in several places on the western side of the estuary. One sample of peat (CM1.2, Fig. 3 and Table 2) was taken for dating. In this segment, the examined samples showed few or no foraminifera.

\subsubsection{Unit $\mathrm{V}$ (À16.2 to $0 \mathrm{~m})$}

The sedimentary sequence between $16.2 \mathrm{~m}$ and the top of the borehole is sand dominated. In this sequence, six sub-units were discerned, each one showing a fining upward trend from medium or fine sand to silty sand, silt and clay with root and vegetal remains. The contacts between these sub-units are sharp, erosive. In the fine sandy layers, flaser structures were observed. Vegetal remains graded from dissipated in a mineral matrix to accumulated in peaty centimetre-thick horizons. This repeated pattern was occasionally interrupted by centimetre-thick coarse sandy layers. Mollusc assemblages were similar to the previous sedimentological units (Table 3 ), with $\mathrm{C}$. edule being more frequent and with four new bivalve species not found in the preceding unit. In few samples, the bioclastic fraction composed mostly of bivalves and gastropods represented ca. $70 \%$ of the $>0.250 \mathrm{~mm}$ fraction and also contained skeletal fragments of echinoderms and sponges. Well preserved valves of $C$. glaucum were taken for dating (sample CM1.1, Fig. 3 and Table 3).

In the uppermost and lowermost parts of this unit, the foraminifera assemblage is poor both in individual numbers and/or species. However, samples from the intervals 13.60 to $12.70 \mathrm{~m}$ and 10.60 to $9.37 \mathrm{~m}$, contained a significant number of calcareous species although they are not more than $10 \%$ of total. The assemblage is dominated by $\mathrm{H}$. depressula and $\mathrm{A}$. beccarii.

The upper part of this unit, starting at $1.7 \mathrm{~m}$ is anthropogenic soil.

\subsection{Borehole $\mathrm{CM} 2$}

$\mathrm{CM} 2$ is the shortest core among the four collected. It reached the Mesozoic substratum at $10.56 \mathrm{~m}$ depth. It is located in a confined sector of the estuary close to a subsidiary tidal channel of Guadiana. The area is occupied at present by the artificial salt ponds and according to XVII and XVI century maps was a part of a barrier and dune sheltered water way, which connected the Guadiana Estuary to the Ria Formosa Lagoon to the west. In the sedimentary column, three sedimentological units (Fig. 5) were distinguished. This core contained high average total numbers of individual foraminifera, ranging from 0 to 3248 individuals per $10 \mathrm{~cm}$.

\subsubsection{Unit I (À10.5 to À9.9 m)}

Above the Jurassic limestone substratum lies a 0.60 $\mathrm{m}$ pebbly layer with two different lithologies. Close to the bottom, the autochthonous pebbles consist entirely of limestone, while the upper pebbles of this sedimentological unit consist of well-rounded quartzite and graywacke fragments supported by a sandy matrix.

\subsubsection{Unit II (À9.9 to À8.4 m)}

This interval is composed of dark grey (2.5/10Y) micaceous fine sand, moderately to poorly sorted, containing a few quartz and schist pebbles and millimetre-scale laminae of silt. The upper $30 \mathrm{~cm}$ is composed of fine sand containing eroded bioclasts, interlayered with clay. The samples observed in this unit was barren of foraminifera both carbonate and agglutinated and the very scarce shells were unidentifiable, due to their bad state of preservation. In the absence of identifiable mollusc skeletons, shell debris were used for dating (sample CM2.3, Fig. 5 and Table 2).

\subsubsection{Unit III (À8.4 to $0 \mathrm{~m}$ )}

The uppermost segment, which begins at $8.4 \mathrm{~m}$ depth and continues to the surface, is a monotonous 


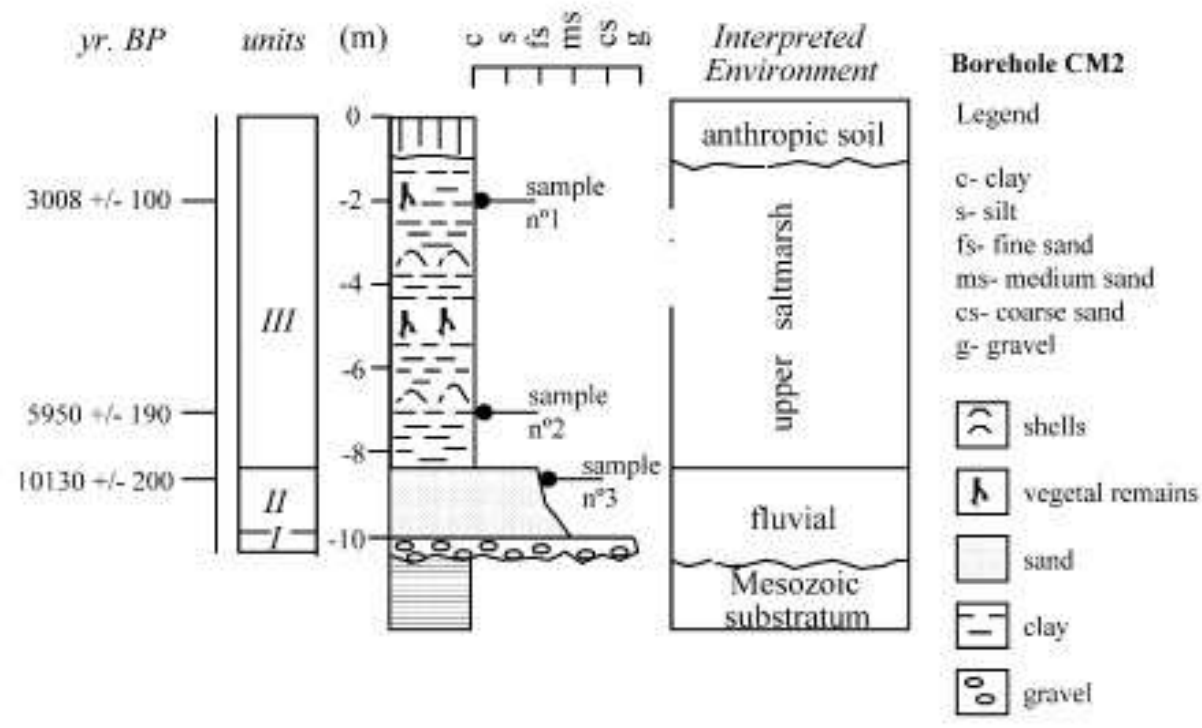

Fig. 5. Stratigraphic column from borehole CM2 and the inferred depositional environments. Depth referred to the borehole mouth elevated at $1 \mathrm{~m}$ above MSL.

dark clay $(5 Y, 3 / 1)$ sequence, rich in plant remains. Layers enriched in bivalve shells were observed. Sample CM2.2, (Fig. 4 and Table 2) used for dating was a valve of Acanthocardia tuberculata.

The uppermost level dated in this profile was a peat layer (sample CM2.1, Fig. 5 and Table 2) that probably accumulated in an ephemeral brackish pond. Such semiconfined ponds exist in several areas of the present estuary and accumulate fresh water during the rainy period (October-May), drying in the summer.

From the top of the previous unit at $8.54 \mathrm{~m}$, to 3.40 $\mathrm{m}$, average values of foraminifera fauna were over 2000 , dominated by $A$. beccarii and $\mathrm{H}$. depressula with significant percentages of Elphidium spp. In the most superficial $2.50 \mathrm{~m}$ of the core, foraminiferal assemblage contained a low number fauna of seven individuals dominated by Trochammina spp.

\subsection{Borehole $\mathrm{CM} 3$}

This borehole is located about $3 \mathrm{~km}$ south of CM1, as well as close to the main estuarine channel (Fig. 2 and Table 1) and within the salt marsh affected sporadically by spring tides. The paleozoic substratum was reached at the depth of $36 \mathrm{~m}$. Analyses of sedimentological facies distingue four units (Fig. 6), in which 20 samples were examined in terms of their foraminifera content. Total numbers of individuals ranged from 0 to 3328 per $10 \mathrm{~cm} 3$ of sediment and corresponded to 0 and 20 species, respectively. The macrofauna is reported in Table 3.

\subsubsection{Unit I (À36 to À30.8 m)}

Shales and graywackes are overlain by a 5 -m-thick gravelly layer. Lithologically, $80 \%$ of the pebbles and cobbles are quartz and quarzitic and $20 \%$ are graywackes and shale fragments. Their external features are identical to those described in CM1 borehole.

\subsubsection{Unit II (À30.8 to À16.5 m)}

Overlying the gravelly layer, is $14.3 \mathrm{~m}$ of organic matter-rich dark grey clay $(5 \mathrm{Y}, 3 / 1)$ with plant detritus and bioclasts. Molluscs (Table 3 ) were in general poorly preserved due to the advanced stage of dissolution of their skeletons, however, few specimen could be identified. A 5-cm-long piece of well preserved wood was found in this clay and was used for dating (sample CM3.4, Fig. 6 and Table 2).

The lowermost samples of this unit between 31.0 and $21.0 \mathrm{~m}$, contained fauna of agglutinated foraminifera species dominated by inner linings of Trochammina spp. In the upper portion from 21.0 to $16.5 \mathrm{~m}$, foraminifera were calcareous, dominated by $A$. beccarii and $\mathrm{H}$. depressula (at $18.15 \mathrm{~m}$ ) and by Discorbis spp., Elphidium spp. and Quinqueloculina spp. in the other samples. 


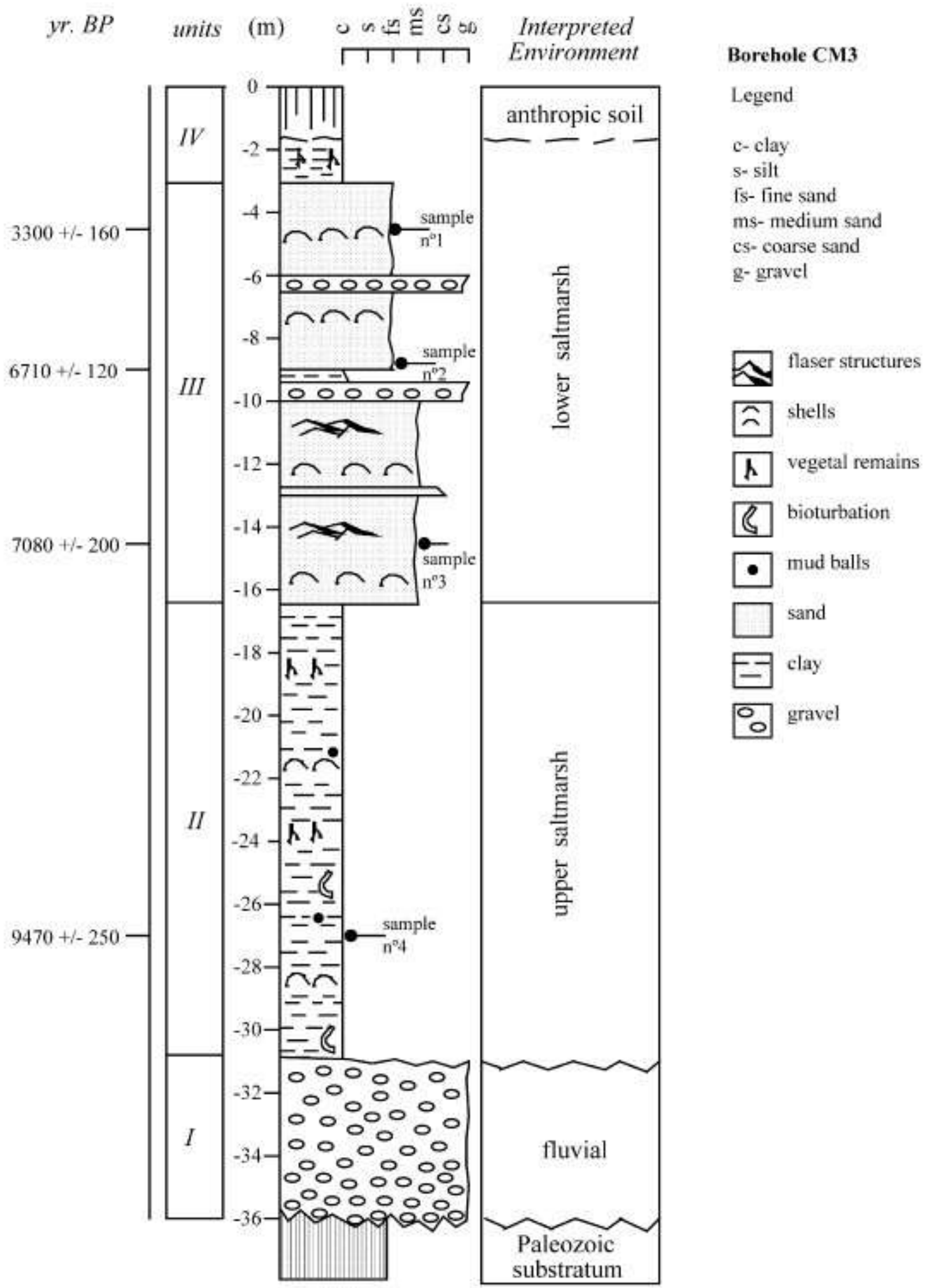

Fig. 6. Stratigraphic column from borehole CM3 and the inferred depositional environments. Depth referred to the borehole mouth elevated at $1 \mathrm{~m}$ above MSL. 


\subsubsection{Unit III (À 16.5 to À $3.8 \mathrm{~m})$}

The sediments, similar to those observed in unit III in borehole CM1, range from dark $(5 \mathrm{Y}, 5 / 1)$ medium sand to fine sand exhibiting flaser structures, with occasional centimetre-scale gravel layers.

The mollusc skeletons are better preserved than in the underlying horizon and consequently 12 species of bivalves could be identified pointing to sedimentary environments summarized in Table 3 . The dated samples CM3.1, CM3.2 and CM3.3 (Fig. 6 and Table 2) are all $C$. angulata individual valves.

The foraminiferal fauna is calcareous, dominated by $A$. beccarii and $H$. depressula at $4.8,6.9$ and 16.4 $\mathrm{m}$ and by Discorbis spp., Elphidium spp. and Quinqueloculina spp. in the remaining samples of this unit.

\subsubsection{Unit IV (À3.8 to $0 \mathrm{~m})$}

The top $3.8 \mathrm{~m}$ of the core consists of a black clay with plant remains. The foraminiferal assemblage is dominated by the agglutinated species Trochammina spp. and Ammobaculites sp.

\subsection{Borehole CM4}

The borehole CM4 was situated in the Monte Gordo dune field close to the shoreline and is $5 \mathrm{~m}$ above the MSL (Fig. 2 and Table 1). Five sedimentological units were distinguished in the sedimentary column overlying the Paleozoic substratum at $36 \mathrm{~m}$ depth (Fig. 7). The foraminifera were examined in 24 samples, of which several were barren. However, the samples showing foraminifera revealed the highest numbers ranging from 325 to 4000 individuals per $10 \mathrm{~cm}_{3}$ and it is the only one containing offshore planktonic species.

\subsubsection{Unit I $(36-32.2 \mathrm{~m})$}

The layer overlying directly the Palaeozoic substratum consists of quartz, graywack and shale pebbles that are mostly discoidal, up to 9-cm long with scarce, poorly preserved mollusc remains.

\subsubsection{Unit II $(32.2-28.8 \mathrm{~m})$}

This unit composed of dark grey $(5 Y, 5 / 2)$ silts and silty clays interlayered with more ferruginous ones (10YR, 5/4). Only agglutinated foraminifera were found and the assemblage was dominated by Trochamina spp.

\subsubsection{Unit III $(28.8-25 \mathrm{~m})$}

This unit is a 3.6-m-thick complex sequence of centimetre-scale layers of sand, silt and clay. Fine micaceous sand layers exhibit frequent burrows resulting from bioturbation, filled with reddish clayey sediment. Dark clay levels contain abundant vegetal remains and in few cases had peaty appearance. No foraminifera were observed.

\subsubsection{Unit IV $(25-19.1 \mathrm{~m})$}

This unit begins with a $30-\mathrm{cm}$ gravelly layer followed by $1.5 \mathrm{~m}$ of sands grading to a 4 -m-thick gravel bed barren of any fauna remains. The pebbles, granulometry and mineralogy is analogous to the basal gravel level, mostly quartz and quartzitic.

Peat from a discrete 3-cm layer was taken for dating (sample CM4.4, Fig. 7 and Table 2).

\subsubsection{Unit $\mathrm{V}(19.1-15.8 \mathrm{~m})$}

This unit comprises fine, hardened laminated micaceous sands and silts with frequent ferruginous patches. In the upper part, a thick calcrete level was observed. This unit was barren of fauna.

\subsubsection{Unit VI $(15.8-2.4 \mathrm{~m})$}

This unit begins with a $20-\mathrm{cm}$ gravel layer grading to medium sand rich in mollusc shells (Table 3). The bivalve shells, which frequently belong to offshore species, make up to $50 \%$ of the sediment mass. Samples CM4.1, CM4.2 and CM4.3 (Fig. 7 and Table 2) taken for dating are, respectively: Venus nux, Scrobicularia plana and Corbula gibba.

Between 15.7 and $12.2 \mathrm{~m}$, are two clayey layers separated by $1.1 \mathrm{~m}$ of sand rich in shells. The lower clay level exudes a sulphurous smell and is barren in fauna, probably due to carbonate dissolution. In the upper clay level, the foraminifera fauna is rich in calcareous species, mostly Ammonia, Elphidium, Haynesina and in smaller proportion Discorbis, Quinqueloculina, Glabratella and Brizalina species. Planktonic foraminifera were abundant.

\subsubsection{Unit VII (2.4 to surface)}

This unit comprises medium well sorted sands with root fragments and plant debris but contains no fauna remains. 


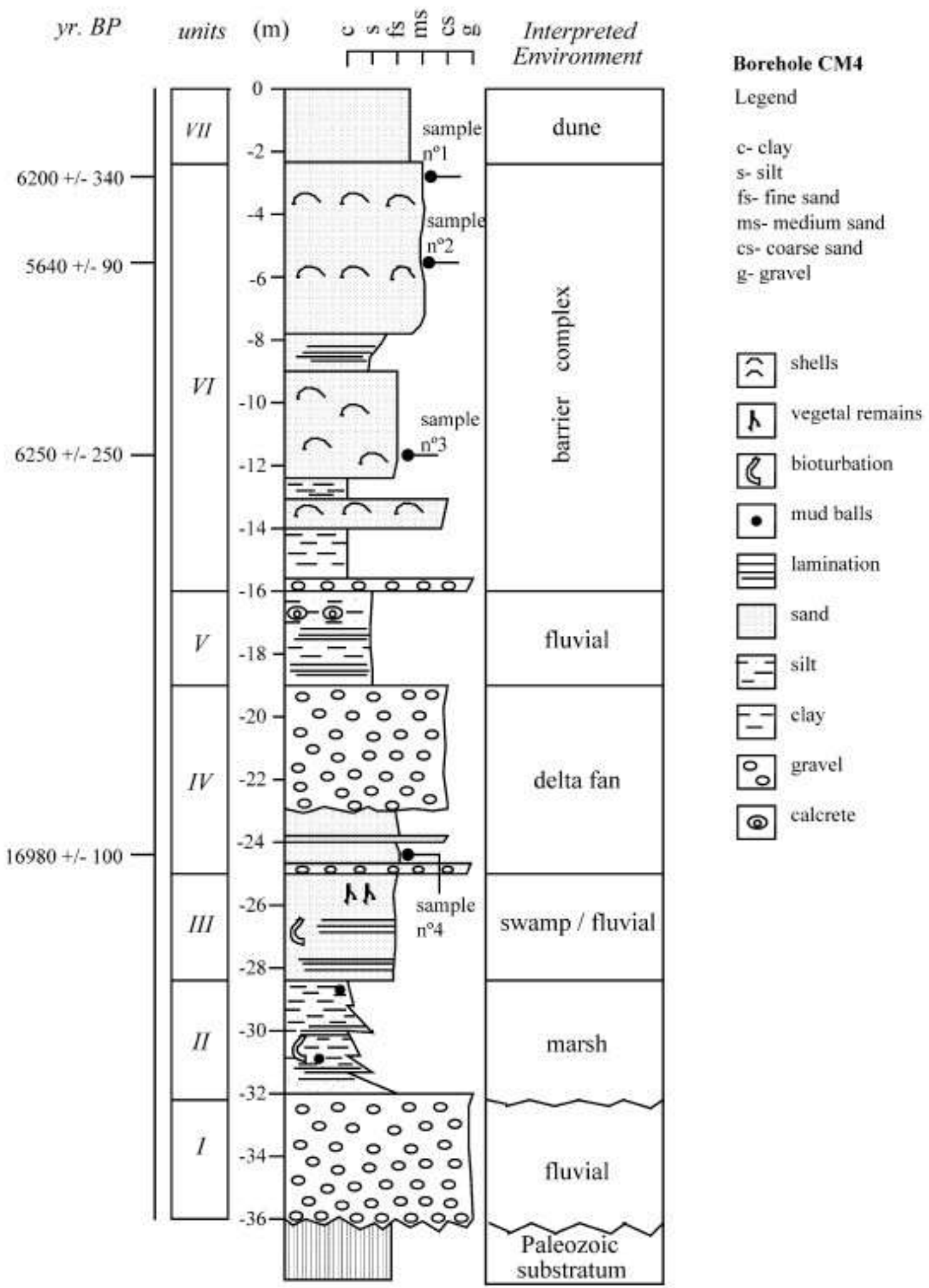

Fig. 7. Stratigraphic column from borehole CM4 and the inferred depositional environments. Depth referred to the borehole mouth elevated at $4 \mathrm{~m}$ above MSL. 


\section{Discussion}

\subsection{Micropaleontology}

In the uppermost sections of all cores, except where they are barren (core CM1, CM4), there is a short section of salt marsh as indicated by the presence of Trochammina spp. (e.g. Scott and Medioli, 1986). In the middle sections, there are a variety of calcareous faunas with typical estuarine faunas in the two cores (CM1 and CM3) farthest up the estuary and more diverse faunas in the cores closer to the sea; in the seawardmost core 4 , there are frequent planktonic species indicating direct transport from offshore into this area. However, in the lowermost sections of three out of four cores, there is a typical salt marsh fauna with Trochammina spp. but usually only inner linings, unlike the surface counterparts of this fauna where the whole test is preserved. This succession represents a standard transgressional depositional sequence where the first marine deposits are upper marsh sediments as the sea first impinges on the shore. As a consequence of the overriding of the marsh by the rising sea, the subtidal estuarine deposits form as it is indicated by the diverse calcareous faunas. There is no indication of a low salinity estuarine sequence between the marsh and estuarine assemblages. The only core not showing this sequence is CM2, because it is situated in the area of shallow-lying Jurassic substratum, where an environmentally abbreviated and a less diverse sedimentary sequence was deposited. The importance of the marsh faunas is that they can provide an accurate sea-level curve for this site, at least where the marsh units are present (Scott and Medioli, 1978, 1986).

The marsh units near the top of CM2 and 3 were not closely dated but there are some limits that could be inferred from comparison with the area of $\mathrm{CM} 3$. In the latter, there is a date of 3300 year BP at $4.6 \mathrm{~m}$ which is about $1 \mathrm{~m}$ below the marsh unit at $3.5 \mathrm{~m}$. In CM2 (where no erosional surfaces were observed), there is a date of 3080 year BP $50 \mathrm{~cm}$ above the marsh unit at $2.5 \mathrm{~m}$. Apparently, sea level was established close about its present level ca. 3000 year BP, if one considers a necessary correction for the compaction of sediments. In the lower sections of cores CM 1 and 3, both situated in the immediate vicinity of the principal estuarine channel, the units close to the marsh sequences were dated 8430 year BP at $28.5 \mathrm{~m}$ (core CM1) and 9470 year BP at $26.9 \mathrm{~m}$ (core CM3). The 9470year date would appear too old since it would represent a sea level higher than the 8430-year level. In fact, the dating was performed on a wood fragment, implying very likely an overestimation of the age of deposition. However, looking at other dates from core CM1, there is a salt marsh level at 36.0 dated at 9500 year BP overlain by an estuarine deposit suggesting a transition to a rapid sea-level rise regime (Fig. 8).

If the date in core CM4 is correct at À $9.75 \mathrm{~m} \mathrm{(5640}$ year BP), this represents a sea level probably not much lower than below present since this is an offshore type environment, and the borehole mouth is elevated ca. 4 $\mathrm{m}$ above the present MSL. Core CM4 represents also a problem of a different type because the deepest date (28.3 m with an age of 16980 year BP on sediment organic matter) is pre-Holocene and is above a welldefined salt marsh unit at $30.4 \mathrm{~m}$. As previously stated, it is most probably a remnant of a interglacial shoreline dating back to the transgression preceding isotope stage $5 \mathrm{e}$ or a stage 3 interstadial highstand.

\subsection{Lithostratigraphy and facies interpretation}

The present estuary of the Guadiana River is narrow, short, tide-dominated and experiencing the final stages of infilling. On the western (Portuguese) side of the terminal segment, a lateral accretion of fine sand/mud banks occurs whereas on the Spanish side, erosion is prevalent. This trend seems to have prevailed for the period of the Holocene infilling which was accompanied by the eastward migration of the axis

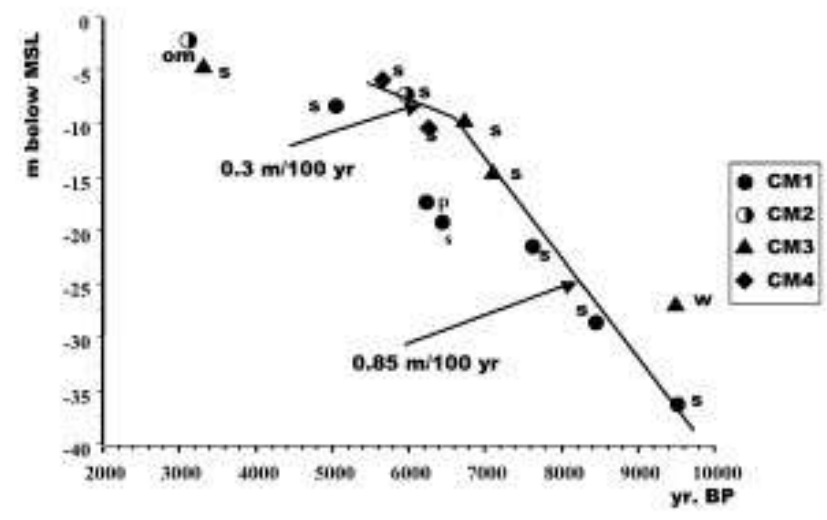

Fig. 8. Age vs. depth graph of the dated sediments from the four studied boreholes. Dated materials (detailed in Table 2): S-shells, $\mathrm{OM}$-disseminated organic matter, $\mathrm{P}$-peat, $\mathrm{W}$-wood. 
of the principal estuarine channel, leading to the observed asymmetry in the incision of the river valley (Fig. 9). During the Last Glacial Maximum, when mean sea level in the Gulf of Cadiz was ca. $120 \mathrm{~m}$ lower than present

(Hernandez-Molina et al., 1994), Guadiana River reached the peak of its eroding capacity. The deepest part of the valley was probably eroded into the gravels deposited during Isotope Stage (IS) 3 (Dabrio et al., 2000), down to the Paleozoic substratum, $80 \mathrm{~m}$ below the present MSL. All four boreholes crossed the gravelly level composed mostly

recycled quartz pebbles from Plio-Pleistocene ranas and fragments of the basement rocks. However, the data from non-cored boreholes indicate that these coarse sediments that may reach 35-m thickness, contain frequent intercalations of finer sediments, a fact also confirmed by geotechnical tests done before the bridge construction.

In borehole CM4, the two pebbly units are separated by very compact oxidized, clearly fresh water swamp/fluvial series dated at 16980 year BP on the organic debris, whose isotopic composition $\left(\mathrm{d}_{13} \mathrm{C}=\right.$ À $28.5 x$ points clearly to a terrestrial origin (Fogel) and Cifuentes, 1993). This suggests that the gravelly river fan that was deposited on a narrow coastal plain experienced at least two phases of accretion, the last probably during the $16000-13000$ year BP period of rapid sea-level rise (Dias et al., 2000). Different depths of the gravel surface observed in the studied boreholes reflects either irregularities of paleorelief (Otvos, 1995) and/or the existence of buried terrace systems produced during lowstand periods (Van Wagoner et al., 1988). The upper gravel level in borehole CM4, separated by fine sediments bearing traces of subaerial exposure, may be a remnant of a prograding delta fan/ braided plain, that was reworked during transgression into a beach ridge (Einsele, 1992) permitting a later anchoring of the coastal sand bar. There is no clear evidence of the retention of finer, sandy sediments in the study area prior to about $10000-11000$ year BP, except in borehole CM2 (unit II) and CM4 (unit V). In the former, a 1-m layer of fine, moderately sorted micaceous sand overlaying the basal gravels was dated to 10130 year BP on few remains of shells that were not identifiable. Neither calcareous nor agglutinated estuarine microfauna, was observed in that layer, thus post-depositional dissolution of marine fauna should be ruled out. Therefore, by taking into consideration the observed mineralogy, we considered this sand to be deposited in a fluvial environment of a small tributary of the main valley. The same origin is attributed to the identical micaceous, laminated fauna, barren sand from borehole CM4, which yielded no datable items. Unpublished data on sediment infill of a small tributary (ca. $2 \mathrm{~km} \mathrm{NW}$ from borehole CM1) gave a ${ }_{14} \mathrm{C}$ age of 10990 year BP on wood fragments recovered also from similar fluvial micaceous sand layer overlying basal gravels at a depth of $48 \mathrm{~m}$. This figure is consistent with Younger Dryas sea level proposed for the Iberian shelf by Dias et al. (2000). Consequently, it seems that the transition from highly energetic fluvial conditions observed in the terminal segment of Guadiana valley at the end of Pleistocene time to the lowenergy central zone of the estuary in the Holocene, left a thin sandy layer deposited in the inner estuary sensu Darlymple et al. (1992). The relatively narrow shelf (ca. $20 \mathrm{~km}$ of the Guadiana mouth) did not permit a more important accumulation of transgressive sands within the inner estuary, which otherwise would occur during spatially more extended approach of the shoreline and a stronger tidal influence (Fitzgerald et al., 2000). The scarcity of sands marking the beginning of the Holocene transgression was observed also in other estuaries of the Gulf of Cadiz by Dabrio et al. (2000). The age at which the estuarine marsh sediment started to cover the fluvial series may be obtained from extrapolation of the depth/age relation of three deepest datings in bore hole CM1, to the depth of the gravel surface. This proceeding was applied within predominantly clayey lithological unit II, embracing two fine to medium sand layers, which are not confined by sharp erosional surfaces. Consequently the continuity of sedimentation of the unit could be assumed. The regression line calculated from these three depth/age relationships has a squared Pearson correlation coefficient $r_{2}=0.997$, yielding the compacted sediment accumulation rate $=0.85 \mathrm{~m} /$ century and the rate of sea level rise above $1 \mathrm{~m} /$ century. The regression line points to the beginning of Holocene sedimentation at a depth of $39 \mathrm{~m}$, which is within the range of sea level values proposed for the Iberian Continental Margin by Dias et al. (2000).

Notwithstanding the observed lithological differences, the Holocene sedimentary infill observed in boreholes CM1 and CM3 record two distinct sedimentary facies with a boundary in the approximate time- 


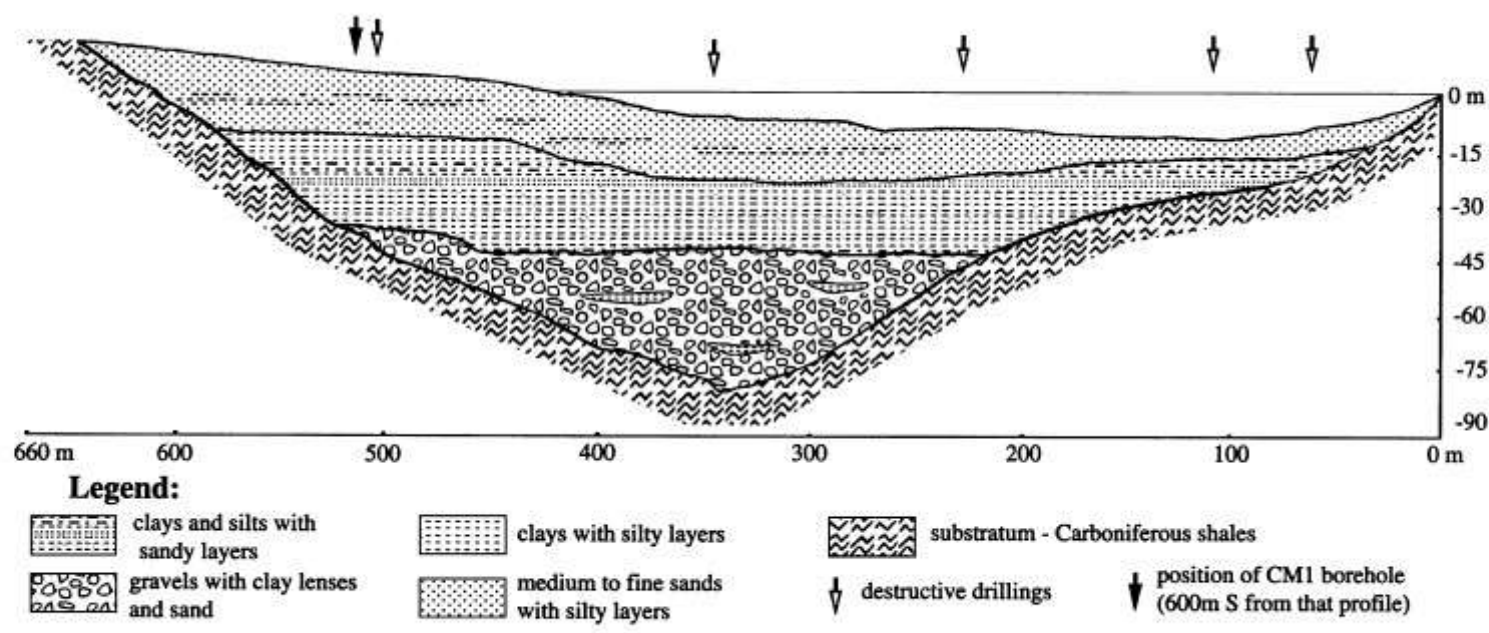

T. Boski et al. / Sedimentary Geology 150 $\mathrm{CM} 3$ combined with the data from noncored drillings done prior to the construction of Guadiana International bridge. 
span from 6200 to 7080 year BP, respectively. In CM1, the boundary is set at $16.2 \mathrm{~m}$ depth. It separates a sequence of rhythmic, finning-up series (unit $\mathrm{V}$ ) interpreted as a point bar facies, from the lower, mostly clayey, bioturbated facies (unit II to IV). In the latter, dissipated vegetal fragments, mud balls, and frequent flaser structures point to an upper intertidal flat environment, under continuous influence of tidal currents. Reddish clayey layers observed in this unit indicate an occasional supply of materials rich in ferruginous pigments, eroded from Plio-Pleistocene formations cropping out along Algarve - Andaluzia coasts (Boski et al., 1999). In fact during the transgression, the drowned fluvial valleys have received alternating fluxes of fluvial and estuarine material as a consequence of an interplay between the rates of sea-level rise, sediment supply and accommodation space (Miall, 1996; Muto and Steel, 2000). Likewise due to the fast sea-level rise in the corresponding period, the fine sediment load could be effectively trapped and fixed (Wood et al., 1993) by the salt marsh vegetation which itself could maintain a constant position in relation to the tidal flooding. The reported discrete centimetre-scale peaty levels indicate the recurrence of brackish/fresh water conditions that most probably occurred in semiconfined ponds. Numerous traces of rootlets indicate that these patches of peat are in situ.

In borehole CM2, unit III is interpreted as an upper marsh, composed almost exclusively of clay deposited in a confined lagoon environment sheltered by the sand spit to the south, occupied at present by Monte Gordo dune field. The lack of any observable discontinuity within this unit indicates that these conditions prevailed throughout the entire period of deposition, i.e. since ca. 7000 year BP. The latter figure was obtained from extrapolation of sedimentation rate between two dated levels 2780 year BP at $4.2 \mathrm{~m}$ depth and 5950 year $\mathrm{BP}$ at $7.1 \mathrm{~m}$ depth. The 30 hand auger drillholes (Santos and Boski, 2000) that were acquired over a surface of about $1 \mathrm{~km} 2$ around CM2, have showed that unit III is laterally homogenous, composed entirely of clayey - silty sediments enclosing levels of well preserved valves of $\mathrm{C}$. edule, Ruditapes decussates and other species that were mentioned above.

Sediments drilled between 31.2 and $16.5 \mathrm{~m}$ (unit II) in borehole $\mathrm{CM} 3$, belong to a remarkably homogeneous facies of clays, very rich in vegetal remains with some bioclastic deposits from channel lags. These facies are typical for confined marshes developed within the reaches of the central estuarine basin where agglutinated foraminifera species dependent on fine sediment, account for almost $100 \%$ of the entire assemblage. The two ${ }_{14} \mathrm{C}$ dates so far obtained (9470 year BP at 26.9 and 7080 year BP at $14.5 \mathrm{~m}$ point once more to conditions of rising sea level at an accelerated pace of $0.6-1 \mathrm{~m}$ per century. Lithofacies from 16.4 to $1.5 \mathrm{~m}$ depth, are mostly fine sand with frequent channel lags, indicating a shift to an environment of increasing tidal energy. The observed replacement of the upper marsh foraminifera by lower marsh species (Gehrels and Plassche, 1999) ca. 7500 -7000 year BP, must have occurred when the sea-level rise became faster than marsh accretion. Combining these figures (considering the sediment compaction) with the recent dating of the submerged rocky shore ridges on Algarve shelf by Teixeira (1999) that indicate sea level of À $20 \mathrm{~m}$ below the present at 7400 year BP and $\mathrm{A} 11 \mathrm{~m}$ below the present at 5860 year BP, suggests that shelf sands became an important component of the estuarine infill between 6500 and 7000 year BP. According to Zazo et al. (1994) in that period, the first phase $(\mathrm{H} 1)$ of barrier progradation along the Gulf of Cadiz coasts began, which enabled the enclosing of coastal lagoons (Bettencourt, 1994). The simplified synthetic section through the sedimentary fill of the estuarine valley obtained from the lithological columns in boreholes CM1 and CM3 and noncored drillings is shown in Fig. 9.

Of the four cores considered, the sedimentary column of the CM4 borehole is certainly the most complex. Two gravel units (I and IV) enclose the salt marsh sediments (unit II) overlain by a swamp/creek laminated and hardened deposit (unit III) that experienced prolonged subaerial exposure inferred from presence of carbonate nodules and oxidized levels. Further to the west in the Gulf of Cadiz, in the Estuaries of Tinto, -Odiel and Guadalete Rivers, similar sequences were attributed to highstands during the isotope stage (IS) V, ca. 128000 year BP (Zazo, 1999) or to the IS III highstand (Dabrio et al., 2000), ca. $25000-30000$ year BP. The first evidence of marine sedimentation in predominantly sandy unit $\mathrm{VI}$ is the shell rich, gravel layer at $15.2 \mathrm{~m}$. The existing datings 6250 year BP at À $15.2 \mathrm{~m}, 5640$ year BP at A $9.7 \mathrm{~m}$ and 6200 year BP at $\hat{A} 7 \mathrm{~m}$ point to (with all necessary reserves imposed by the highly dynamic environment) 
rapid accretion of a coastal bar. The uppermost $3 \mathrm{~m}$ of sands are barren of any fauna at macro- and microscopic scale and contain abundant floral remains, thus their deposition occurred in a subaerial environment of the coastal dune system. Assuming that the period of the Upper Holocene was characterised by a relatively stable sea level (Dias et al., 2000), the final stage of infilling of the estuary could be a consequence of anthropic activities (mainly deforestation in the drainage basin), as it was deduced from archaeological sources (Chester and James, 1991) and the navigation maps published from XVI Century onwards (Morales, 1997).

\section{Conclusions}

Four cored boreholes were drilled through the entire sequence of Quaternary sediments on the Portuguese side of the terminal segment of Guadiana River.

The presented analyses of paleofacies inferred from sedimentological and paleontological features of the sediments deposited in the terminal part of Guadiana fluvial paleovalley, is a first attempt to establish the sequence of events that led to the formation of the Guadiana River estuary in its present form. The valley was incised in Carboniferous rocks to a depth attaining À $80 \mathrm{~m}$ below the present mean sea level. Gravelly delta fan sediments that were described also in other estuaries to the west in the Gulf of Cadiz, line the bedrock valley during early phases of transgression. These accumulated after or during previous high stands, most probably during the isotopic stages 5 and 3 .

To its end, the fluvial phase in terminal part of Guadiana Valley left on top of the gravels a thin veneer of fine micaceous sands lain ca. $11000-10000$ year BP. An accelerated phase of infilling of the estuary by clayey sediments, containing the salt marsh foraminifer Trochammina, began at ca. 9800 year BP when the sea level was about $39 \mathrm{~m}$ below the present. Between 7500 and 7000 year BP, the central part of the estuary started to accommodate coarser sediments, partially introduced from the shelf, whereas in marginal lagoons clay deposition continued. Sedimentation also seems to have kept pace with sea level here as indicated by the thick salt marsh succession. At ca. 6500 year BP, the phase of fast sea-level rise (over $1 \mathrm{~m} /$ century) termi- nated, leading to enclosing of lagoonal bodies behind sand spits in the vicinity of the estuary and to predominantly sandy sedimentation within the estuary. The sea level close to the present was attained at about 5000 year BP after a period of slower rise (below $0.5 \mathrm{~m} /$ century). Navigation maps indicate that since XVI Century the water area within the estuary was steadily decreasing.

\section{Acknowledgements}

This research was financed by European Union INTERREG II programme, DISIPOL Project (Sediment Dynamics and Pollutant Dissipation in Guadiana River Estuary) and is a Centre for Marine and Environmental Research (CIMA) contribution to UNESCO IGCP 437 project. We are grateful to the anonymous editorial reviewers and Charles $\mathrm{H}$. Fletcher (University of Hawaii), who provided many useful suggestions that have considerably improved both content and style of the manuscript.

\section{References}

Aguirre, M.L., Farinati, E.A., 1999. Taphonomic processes affecting late Quaternary molluscs along the coastal area of Buenos Aires Province (Argentina, Southwestern Atlantic). Palaeogeogr., Palaeoclimatol., Palaeoecol. 149, 283 - 304.

P., 1994. Les Environnements Sedimentaires de la Cote Sotavento (Algarve, Sud

Portugal) et leur Evolution Holocene et Actuelle. PhD thesis, Univ. Bordeaux, Bordeaux, 413 pp.

Borrego, J., Morales, J.A., Pendon, J.G., 1993. Holocene filling of an estuarine lagoon along the mesotidal coast of Huelva: The Piedras River mouth, southwestern Spain. J. Coast. Res. 9, $242-254$.

Boski, T., Moura, D., Machado, L.M., Bebianno, J.M., 1999. Trace metals in the coastline of Algarve I-associations, origins, and remobilization of natural component. Bol. Inst. Esp. Oceanogr. $15,74-81$

oriental. Bol. Soc

$$
\text { "Cabral, J., 1995. Neotectonica de Tras-os Montes }
$$

Geol. Port., Lisboa 24, 193 - 197

Chester, D.K., James, P.A., 1991. Holocene Alluviation in the Algarve, southern Portugal; case for an anthropogenic cause. J. Archaeol. Sci. 18, $73-87$.

Ferreira, O., 1996. The retreat of 'Correia, F., Dias, J.A., Boski, T., the Eastern Quarteira cliffed coast (Portugal) and its possible causes. In: Jones, P.S., Healy, M.G., Williams, A.T. (Eds.), Studies in Coastal Management. Samara Publ., Cardigan, UK, pp. $129-136$.

J.L., Lario, J., Zazo, C., Borja, F., Gonzalez, A., 
1995. The Guadalete Estuary during the Holocene times (Bay of Cadiz, Spain). Mediterranean and Black Sea Shorelines (INQUA) Newsletter 17, 19-22.

Dabrio, C.J., Zazo, C., Goy, J.L., Sierro, F.J., Borja, F., Lario, J., 'Gonzalez, J.A., Flores, J.F., 2000. Depositional history of estuarine infill during the last postglacial transgression (Gulf of Cadiz, Southern Spain). Marine Geology 162, 381 - 404.

Darlymple, R.W., Zaitlin, B.A., Boyd, R., 1992. Estuarine facies models: conceptual basis and stratigraphic implicatios. J. Sediment. Petrol. 62, $1130-1146$.

Rodrigues, A., Magalhaes, F., 2000. Coast line evolution in Portugal since the last glacial maximum until present-a synthesis. Mar. Geol. 170, 177 - 186.

Einsele, G., 1992. Sedimentary Basins. Evolution, Facies and Sediment Budget. Springer, Berlin, $628 \mathrm{pp}$.

Fitzgerald, D.M., Buynevich, I.V., Fenster, M.S., McKinlay, P.A 2000. Sand dynamics at the mouth of a rock-bound tide-dominated estuary. Sediment. Geol. 131, $25-49$.

Fogel, M.L., Cifuentes, L.A., 1993. Isotope fractionation during primary production. In: Engel, M.H., Macko, P.L. (Eds.), Organic Geochemistry. Plenum, New York, 860 pp.

Gehrels, W.R., Plassche, O., 1999. The use of Jadammina macrescens (Brady) and Balticammina pseudomacrescens Bronnimann, Lutze and Whittaker (Protozoa: Foraminiferida) as sealevel indicators. Palaeogeogr., Palaeoclimatol., Palaeoecol. 149, $89-101$.

Goy, J.L., Zazo, C., Somoza, L., Dabrio, C.J., Lario, J., Borja, F., Sierro, F.J., Flores, J.A., 1996. Global and reginal factors controlling changes of coastlines in South Iberia (Spain) during Holocene. Quat. Sci. Rev. 15, $773-780$.

Granja, H., Froidefond, J.-M., Pera, T., 1984. Processus d'evolution morpho-sedimentaire de la Ria Formosa (Portugal). Bull. Inst. Geol. Bassin Aquitaine, Bordeaux 36, 37 - 50.

'Hernandez-Molina, F.J., Somoza, L., Rey, J., Pomar, L., 1994. Late Pleistocene - Holocene sediments on the Spanish continental shelves: a model for very high-resolution sequence stratigraphy. Mar. Geol. 120, $129-174$

Martin-Serrano, A., Molina, E., 1989. Montes de Toledo y Extrem-

del Cuaternario de Espana. Instituto Tecnologico Geominero de Espana, Madrid.

Miall, A.D., 1996. The Geology of Fluvial Deposits. Springer, Berlin, $582 \mathrm{pp}$.

Morales, J.A., 1997. Evolution and facies architecture of the mesotidal Guadiana River delta (S.W. Spain - Portugal). Mar. Geol. $138,127-148$.

Mougenot, D., 1988. Geologie de la Marge Portuguese. These de 'Dotorat detat es Sciences Naturelles, Paris, $257 \mathrm{pp}$

Unidades litostratigraficas do Plioceni-

"Moura, D., Boski, T., 1999. and below the sediment - water interface. Palaeogeogr., Palae106.

'co e Plistocenico no Algarve. Comun. Inst. Geol. Min. 86, 85 Wood,

Muto, T., Steel, R.J., 2000. The accommodation concept in sequence stratigraphy: some dimensional problems and possible redefinition. Sediment. Geol. 130, 1- 10.

Otvos, E.G., 1995. Multiple Pliocene - Quaternary marine highstands, Northeast Gulf costal plain-fallacies and facts. J. Coast. Res. 11, $984-1002$. oclimatol., Palaeoecol. 149, $283-304$.

Pereira, A.R., 1992. A Geomorfologia da Margem Continental Por-

Continental e Li-

Linha de Acca o deß 'toral. Centro de Estudos Geogra ficos

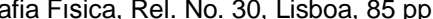
A.F., Almeida, F., Carvalho, D., Monteiro, J.M., 1979. Introduction a la Geologie Generale du Portugal. Servicos Geologigos deß Portugal, Lisboa, $114 \mathrm{pp}$. tary infill in the two areas of contrasted sedimentary dynamic of Guadiana Estuary. In: Carvalho, S.G., Gomes, V.M., Pinto,

Bacia Hi-

'T.F. (Eds.), Os Esuarios de Portugal e os Planos de

drografica. Eurocoast Association Portugal, Lisboa, pp. 45 - 53. drevis J.O.R., 1993. A device for precision splitting of micropaleontological samples in liquid suspension. J. Paleontol. $67,151-154$

Scott, D.B., Medioli, F.S., 1978. Vertical zonations of marsh foraminifera as accurate indicators of former sea-levels. Nature 272, $528-531$.

Scott, D.B., Medioli, F.S., 1986. Foraminifera as sea-level indicators. International Correlation Programme, Project 61. In: van de Plassche, O. (Ed.), Sea-level Research: A Manual for the Collection and Evaluation of Data. Geo Books, Norwich, UK, pp. $435-456$.

Teixeira, S.B., 1999. Contribuicao para o conhecimento da evolucaoß $\AA^{\sim}$

(Algarve-Portugal) nos ultimos 8000 anos. Al-Ulya, 1 - 20.

'Trentesaux, A., Stolk, A., Berne, S., 1999.

Sedimentology and stratigraphy of a tidal sand bank in the southern North Sea. Mar. Geol. 159, $253-272$. Sarg, J.F., Loutit, T.S., Hardenbol, J., 1988. An overview of the fundamentals of sequence stratigraphy and key definitions. In: Wilgus, C.K., Hastings, B.S., Kendall, C.G., Posamatier, H.W.,

adura; mapa Ross, C.A., van Wagoner, J.C. (Eds.), Sea Level Changes: An Integrated Approach. Soc. Econ. Paleontol. Mineral. Spec. Publ., vol. 42, pp. $39-45$.

'Vidal, J.R., Caceres, L.M., Ramirez, A.R., 1993. Modelo evolutivo da rede fluvial Cuaternaria en el suroeste de la peninsula lberica.

"Actas 3a Reuniao do Quaternario Iberico,

Universidade de Coimbra, Coimbra, 93 - 96

Walker, S.E Goldstein, S.T. 1999. Taphonomic tiering: experi-

rate of base-level fluctuation on coastal plain, shelf and slope depositional systems: an experimental approach. Spec. Publ. Int. Assoc. Sedimentol. 18, $43-53$.

Zazo, C., 1999. Interglacial sea levels. Quaternary international. Quat. Int. 55, $101-113$

Zazo, C., Goy, J.L., Somoza, L., Dabrio, C.J., Belluomini, G., Improta, S., Lario, J., Bardaji, T., Silva, P.G., 1994. Holocene sequence of sea level fluctuations in relation to climatic trends in the Atlantic - Mediterranean Linkage Coast. J. Coast. Res. 10 (4), $933-945$.
Santos, A., Boski, T., 2000. The comparison of Holocene sedimen-

Van Wagoner, J.C., Posamatier, H.W., Mitchum, R.M., Vvail, P.R., 